\title{
Margaret McCartney: Health technology and the modern inverse care law
}

\author{
Margaret McCartney general practitioner
}

Glasgow

As Jeremy Hunt left his position as England's health secretary he welcomed his successor with a tweet: "Couldn't ask for a better successor than @ matthancock to take forward long term NHS plan with his brilliant understanding of the power of technology. The new NHS app will be in safe hands!"1

The only thing I knew about Matt Hancock was that he already had an app of his own. This app was accused of basic privacy flaws (such as allowing access to photographs on a smartphone even when the user had denied this option: it has now been updated). ${ }^{2}$ We all make mistakes, we're all human, etc.

Hancock told an audience this year that "My GP is through the NHS on Babylon Health—it's brilliant." ${ }^{33}$ But, with $£ 250000$ of taxpayers' money being used to evaluate the broader effects of this virtual service on NHS primary care, ${ }^{4}$ we don't know whether it's affordable or viable. And we (still) don't know whether the app that comes with the service is safe.

A senior NHS executive once told me that non-evidence based policy making was simply a side effect of a publicly funded NHS. Politicians get their way with daft ideas because they're elected, I was told, and if we want an NHS we must simply suffer the consequences of political meddling.

But non-evidence based policy making is the ruin of the NHS and, unchallenged, is perfectly capable of finishing it off. There's a relation between wasteful policy making and resources. And, where resources are limited, who gets access to them?

We know that, too often, those most in need are the least likely to receive adequate care. This is the inverse care law, described in 1971 by Julian Tudor Hart, who died this month, ${ }^{5}$ in one of the most profound and classic papers ever written about healthcare.

It's worth committing one phrase from the paper's abstract to memory: "The availability of good medical care tends to vary inversely with the need for it in the population served. This inverse care law operates more completely where medical care is most exposed to market forces, and less so where such exposure is reduced."
People who get what they want don't necessarily get what they need; people who get what they need don't necessarily get what they want.

A further modern irony makes me worry about Hancock's enthusiasm for a healthcare technology whose risks and benefits have yet to be fully assessed. People are harmed by too much medicine. So, care led by demand makes people into patients when they can't benefit and can only be harmed, yet people who need to be patients can't access the care they need-the patient paradox. We waste resources while everyone's health gets worse overall.

The fact that health inequalities persist on such a grand scale despite the moral founding principles of the NHS-being free at the point of need-is shameful. Why should poor, learning disabled, or mentally ill people be destined for shorter and less healthy lives?

Technology should be a power for good, but for it to benefit patients we need to answer some important questions.

Commissioned reviews get waves of publicity before they sink, forgotten. We need system change: every new policy must be interrogated for evidence of benefit and harm, opportunity cost, and the potential to benefit—or worsen-health inequalities.

Competing interests: See www.bmj.com/about-bmj/freelance-contributors/margaretmccartney.

Provenance and peer review: Commissioned; not externally peer reviewed.

Hunt J. @jeremy_Hunt. Twitter 9 July 2018.

2 Brennan D. MP Matt Hancock's app is a privacy "comedy of errors." International Business Times 1 Feb 2018. https://www.ibtimes.co.uk/mp-matt-hancocks-app-privacy-comedyerrors-1658041.

3 Borland S, Kent Smith E. New health secretary Matt Hancock uses controversial app to see GP. Daily Mail 10 July 2018. www.dailymail.co.uk/news/article-5939971/New-HealthSecretary-pays-25-GP-10-minutes-internet.html.

$4 \quad$ NHS Shared Business Services. GP at Hand Independent Evaluation on behalf of NHS Hammersmith and Fulham CCG. April 2018. https://www.contractsfinder.service.gov.uk/ Notice/d74c2a37-412c-4d86-ac3b-48429f903518.

5 Warren P. Julian Tudor Hart: visionary general practitioner who introduced the concept of the "inverse care law.". BMJ 2018;362:k305210.1136/bmj.k3052

6 Hart JT. The inverse care law. Lancet 1971;297:405-12. 10.1016/S0140-6736(71)92410-X 4100731 
Published by the BMJ Publishing Group Limited. For permission to use (where not already granted under a licence) please go to http://group.bmj.com/group/rights-licensing/

permissions 